\title{
Meteorological variability and infectious disease in Central Africa: a review of meteorological data quality
}

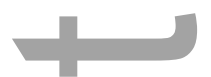

Alexandra Heaney, ${ }^{1}$ Eliza Little, ${ }^{2}$ Sophia $\mathrm{Ng},{ }^{3}$ and Jeffrey Shaman ${ }^{4}$

1,2,4 Department of Environmental Health Sciences, Columbia University, New York, New York. ${ }^{3}$ Department of Epidemiology, University of Michigan, Ann Arbor, Michigan

Address for correspondence: Alexandra Heaney, Department of Environmental Health Sciences, Columbia University, 722 West 168th St., New York, NY 10032. akh2148@ cumc.columbia.edu

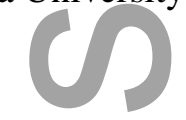

Short title: Meteorology and infectious disease in C. Africa

Abstract

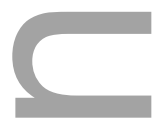

Central African countries may bear high climate change-related infectious disease burdens because of pre-existing high rates of disease, poor healthcare infrastructure, land use changes, and high environmental change vulnerabilities. However, making connections between climate and infectious diseases in this region is hampered by the paucity of high-quality meteorological data. This review analyzes the sources and quality of meteorological data used to study the interactions between weather and infectious diseases in Central African countries. Results show that $23 \%$ of studies used meteorological data mismatched with the disease spatial scale of interest. Use of inappropriate weather data was most frequently identified in analyses using meteorological station data or gridded data products. These findings have implications for the interpretation of existing analyses and provide guidance for the use of climate data in future analyses of the connections between meteorology and infectious diseases in Central Africa.

Keywords: climate; infectious disease; Central Africa; data quality

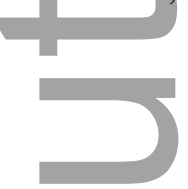

This is the author manuscript accepted for publication and has undergone full peer review but has not been through the copyediting, typesetting, pagination and proofreading process, which may lead to differences between this version and the Version of Record. Please cite this article as doi:

10.1111/nyas.13090.

This article is protected by copyright. All rights reserved. 


\section{Introduction}

African countries currently contribute little to the total global emissions of greenhouse gasses; however, they bear high climate change-related health burdens, ${ }^{1}$ including the direct physiological effects of increasing temperatures, reduced agricultural productivity, water insecurity, and changing patterns of vector-borne diseases. In Africa, infectious diseases remain a leading cause of mortality. Half of all years of life lost are due to infectious diseases, ${ }^{2}$ such as HIV, tuberculosis, malaria, and waterborne diarrheal diseases. ${ }^{2-5}$

Within the African continent, Central Africa — defined as Angola, Burundi, Cameroon, Central African Republic, Chad, Equatorial Guinea, Gabon, South Sudan, Republic of Congo, Rwanda, and Uganda - has a high burden of infectious disease and has been subject to recurrent outbreaks of emergent infectious diseases, such as Ebola. ${ }^{6}$ This region remains predominantly forested with high biodiversity because of a historical reliance on oil and mining, rather than forestry and agriculture; however, recent population growth has motivated an increase in logging and the number of road networks penetrating uninhabited areas. ${ }^{7}$ With this increasing infiltration into previously undisturbed forest ecosystems, humans, livestock, and wildlife are mixing in new ways, and the risk of emerging infectious diseases is considered to be high. ${ }^{8-10}$

Environmental change vulnerability, which is a combined measure of a community's exposure to climatic change, its sensitivity to these changes, and its ability to adapt, ${ }^{11,12}$ is particularly high in Central African countries. Underlying vulnerabilities include existing heat, food, and water stress, disease transmission, and poor healthcare infrastructure. Given these susceptibilities, Central African countries may experience a greater impact of climate change on human infectious diseases. Despite awareness of Central Africa's vulnerability to climate change, ${ }^{13}$ there remains limited empirical evidence on the influence of climate change on infectious diseases for this region, as well as Africa overall. ${ }^{14,15}$

In light of climate change, it is important to understand the influence of meteorological conditions on infectious diseases. Such research is particularly important in areas where climate change is expected to have a greater impact. However, in areas such as Central Africa, the data to make these connections are often lacking. In this paper, we aim to review the literature on meteorology and infectious diseases in Central Africa; to assess the types and quality of the meteorological data being used to study weather and infectious diseases in Central Africa; and to use these findings to provide suggestions related to meteorological data use in future analyses of weather and infectious diseases in this region. We begin with a review of the types of meteorological data available and description of our review methods.

\section{Meteorological data}

This article is protected by copyright. All rights reserved. 
Studies of climate and infectious disease, disease monitoring, surveillance, and early warning systems depend on the availability of reliable meteorological information. Existing meteorological data, including variables such as temperature and precipitation, are derived from ground-based measurements, satellite measurements, or interpolated gridded datasets. This section summarizes the quality and availability of such datasets in Central Africa; see Table 1 for specific data sources.

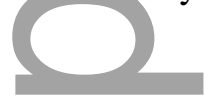

\section{Ground-based measurements}

Ground-based measurements are the most direct measure of temperature and precipitation at the surface. However, ground-based observation networks report inadequate coverage in Africa both spatially (i.e., the density of gauges) and temporally (i.e., intermittent, erratic recordings). ${ }^{16-18}$ Additionally, there has been an observed decline in gauge observations across Africa in the past decade(s), ${ }^{19}$ and existing stations tend to be biased toward higher elevations. ${ }^{20}$ Ground-based measurements are particularly sparse and intermittent in Central Africa (Fig. 1, Table 2). Very few meteorological stations provide data within each Central African country, and the existing observations have poor temporal coverage.

\section{Satellite measurements}

Precipitation and, to a lesser degree, temperature are variable in space and time and require highgauge density for accurate measurement. Given the low density of ground-based observations in Central Africa, satellite-based estimates are an attractive alternate source for meteorological data. While there is controversy surrounding the relative accuracy of satellite-derived precipitation and temperature observations, many researchers have concluded that the observations are of acceptable quality in Africa. ${ }^{21-24}$ These satellite-derived measurements benefit from more regular, even continuous, observation in time and space; however, the spatial resolution of most remotely sensed data is low compared with the localized measurements provided by ground-based observations.

Satellite-based precipitation is measured by thermal infrared (TIR) sensors, microwave sensors, or a combination of both. TIR sensor estimates are best used for estimating precipitation in convective clouds ${ }^{25}$ and have been shown to do well in Africa because of the predominance of rainfall from deep convective systems. ${ }^{24}$ Microwave sensors are more accurate than TIR estimates but are more limited because of low temporal resolution.

TIR wavelengths are also used for measuring land surface temperature. However, processing is necessary to convert the TIR readings to accurate land surface temperatures. A variety of satellite platforms (e.g., ASTER, Landsat, AVHRR, and MODIS) can provide these estimates of land surface temperature with high temporal and spatial resolution. ${ }^{26}$

\section{Gridded products}

This article is protected by copyright. All rights reserved. 
Gridded products employ spatial interpolation to provide continuous estimates of meteorological conditions in both space and time. These datasets are typically constructed from gauge data, satellite data, or both. Gridded datasets do not sufficiently resolve local conditions to allow local analyses and are intended only for global or regional scale analyses. ${ }^{27}$ Further, gridded gauge-satellite precipitation products have been found to poorly characterize rainfall in Central Africa. ${ }^{28}$ For both satellite-based measurements and gridded climate products, more validation is needed; however, the scarcity of ground-based measurements remains an impediment to such assessments. ${ }^{29}$

\section{Methods}
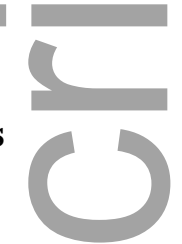

\section{Search strategy and inclusion criteria}

We searched Web of Science for articles on meteorology and infectious diseases in Central Africa, published in English between Jan 1, 1970 and Jun 30, 2015. Search key terms were split into three categories: infectious disease, meteorology, and country. We defined Central Africa as the following 12 countries: Angola, Burundi, Cameroon, Central African Republic, Chad, Equatorial Guinea, Gabon, South Sudan, Republic of Congo, Rwanda, and Uganda. These countries make up an area of 7.5 million sq km, with a total population of about 206 million. ${ }^{30}$ Each search session contained one key term from each category, and searches were carried out using all possible combinations of key terms (Table 3). Studies were included if they pertained to human infectious diseases, included temperature, humidity, and/or precipitation variables in the analyses, and carried out analyses in a Central African country. In order to focus on local and regional scale analyses, all continental and global scale studies were excluded.

\section{Data source extraction}

A data extraction table was created to summarize the meteorological and disease data used in the included papers. The table contains sources, variables included, and spatial scales/resolutions for every dataset used in each paper. Ultimately, sources for meteorological and disease data were aggregated into larger categories.

The meteorological data sources were coded as local meteorological station data, directly measured data (i.e., primary data collection), satellite data, large gridded datasets, hydrological data, seasonal, and unknown. Papers with seasonal meteorological data did not use quantitative data, but instead categorized time periods as hotter/colder or wetter/drier. When the source of meteorological data was not stated in a manuscript, the data source was categorized as unknown.

Disease data sources were classified into five categories: existing human disease datasets, primary collection of human disease data, animal host or vector sampling data, water samples, and species occurrence datasets. Human disease datasets are obtained from any source that aggregates

This article is protected by copyright. All rights reserved. 
human data, such as the World Health Organization (WHO) or local hospitals. Primary collection of human disease data, as well as animal host or vector sampling, implies active collection of disease information from participants or animals.

\section{Spatial mismatch analysis}

The spatial mismatch analysis aimed to determine whether the meteorological data used in each paper were measured at an appropriate spatial scale, given the disease data. First, using maps, information provided in the papers, and online sources, we estimated the geographical region represented by the disease data. Areas were estimated in $\mathrm{km}^{2}$ and then categorized as local (subnational or national) or regional (multinational) spatial scales. Methods for determining spatial mismatch differed on the basis of whether the meteorological data were point estimates or gridded products. Two investigators conducted all analyses separately and compared their results in order to strengthen validity. If disagreements occurred, the investigators reviewed the relevant information together and reached a consensus.

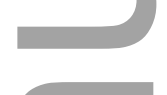

Point estimates. Meteorological point estimates came from meteorological station data and direct measurements by researchers. Papers that used this type of meteorological data either had disease point estimates or disease data covering a prescribed locality. For papers that used disease point estimates, we determined the distance between the disease and the meteorological point estimates (if possible). If this distance was greater than $100 \mathrm{~km}$, we classified a spatial mismatch, as the meteorological data are likely too far away to accurately represent conditions at the site of disease data.

Alternatively, for studies that contained a larger proscribed area of disease data (i.e., data points spanning a geographical region), we estimated the density and placement of meteorological stations within that area (if possible). Spatial mismatch was assigned when the density was less than one station per $100 \mathrm{~km}^{2}$ or the station(s) was further than $100 \mathrm{~km}$ from the disease region.

Gridded data. Many gridded meteorological data products exist. We first determined the types of observations used to create each gridded dataset: satellite, gauge (i.e., meteorological stations), or both. Owing to the sparse and discontinuous nature of gauge data in Central Africa, gauge-only interpolated datasets provide insufficient information for local scale analyses. Hence, we assigned spatial mismatch to any local analysis using gauge-only gridded data. To determine spatial mismatch of gridded data derived entirely or partially from satellite data, we calculated the number of grid cells within the geographical area of the disease data using the gridded-product spatial resolution. If the ratio of grid cells to the disease data area was less than 1 grid cell per $100 \mathrm{~km}^{2}$, we assigned spatial mismatch.

This article is protected by copyright. All rights reserved. 
Spatial threshold. Our justification for choosing a spatial threshold of $100 \mathrm{~km}$ was based on prior estimates of the decorrelation length scale for precipitation. Moron et al. ${ }^{31}$ estimated the spatial scale, defined as the distance at which spatial correlation falls below $r=0.37$, for daily rainfall intensity in tropical regions with diverse topography. They found that spatial correlation decayed exponentially with increasing distance and became much lower than $r=0.37$ for distances greater than $100 \mathrm{~km} .{ }^{31}$ Other papers using satellite data have found similar spatial scales $(95-150 \mathrm{~km})$ for tropical rainfall. ${ }^{32,33}$ Although temperature has a larger spatial scale than rainfall in the tropics, almost every paper included in this review that used temperature estimates also used rainfall estimates in their analyses (96\%). Since all variables need to be spatially matched, we defined $100 \mathrm{~km}$ as the distance demarcation of mismatch. Of the two papers that used temperature estimates only, the spatial resolution of the meteorological data was very high and spatial mismatch was not a problem. Additionally, because Moron et al. ${ }^{31}$ conducted their analyses in topographically diverse regions, the estimated length scale of $100 \mathrm{~km}$ can be used for all topographic contexts.

\section{Results}

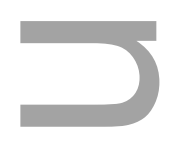

We screened 167 papers obtained from online searches and ultimately included 66 papers written between 1970 and 2015 in this review. The papers investigated a number of infectious diseases, but the majority studied vector-borne disease (61\%), specifically malaria (44\%) (Table 4). Studies were most frequently carried out in Uganda (44\%), Cameroon (22\%), Rwanda (9\%), and Burundi (9\%) (Table S1 in Supporting Information), and only a few pertained to other Central African countries. The number of published papers on meteorology and infectious diseases has increased since 1970. Two-thirds of the papers included in this review were published after 2005 (Fig. S1 in Supporting Information).

\section{Climate data}

The papers used climate data from many different sources (Table 5). For example, one-third (33\%) of the studies used climate data directly from meteorological stations, and 16 papers (24\%) used data from gridded datasets. Fewer studies used satellite data $(n=10,15 \%)$ and directly measured data $(n=$ $8,12 \%)$. None of the papers used hydrological data or modeling. Notably, four papers $(6 \%)$ did not provide a source for the climate data used, and 12 papers (18\%) compared disease metrics across defined seasons instead of using climate data.

\section{Disease data}

Many types of infectious disease data were used (Table 6). Of the papers using human disease data, 36 papers $(55 \%)$ retrieved the data from local healthcare centers or large existing datasets (e.g., WHO, U.S. Centers for Disease Control and Prevention (CDC), local Ministry of Health), whereas 15 papers 
(23\%) collected primary data, such as blood samples or questionnaires. Many papers used data pertaining to animal hosts or vectors, obtained from either primary data collection using trapping or sampling $(n=19,29 \%)$ or from existing species occurrence data $(n=2,3 \%)$. Lastly, five papers $(8 \%)$ collected water samples to measure the presence of infective fecal matter or bacteria.

\section{Spatial mismatch analysis}

Results from the spatial mismatch analysis revealed patterns of mismatch on the basis of the type of climate data used. Findings for each climate data category are discussed below. Table 7 summarizes the distribution of papers with spatial mismatch and papers that did not provide adequate information about their data (referred to as unknown). Overall, the results showed $23 \%$ of papers having spatial mismatch, and mismatch could not be determined in $25 \%$ of papers.

Directly measured. No spatial mismatch was observed between directly measured meteorological variables and health data. Researchers placed the monitoring devices in the locations where health data were collected or available. Although this method often limits the temporal length of data collection, it provides the placement precision needed to avoid spatial mismatch. All papers using directly measured climate data provided sufficient information about their data collection to assess spatial mismatch.

Local meteorological stations. All papers reviewed using meteorological station data directly accessed these data from local government meteorology departments. Of the 22 papers using meteorological station data, 10 (45\%) did not provide enough information to assess spatial mismatch of the data. These papers provided locations for the health data collected, but did not provide locations for the meteorological stations, making it impossible to determine whether the locations of the meteorological stations accurately represent temperature and rainfall in the health area of interest.

We identified spatial mismatch in six $(27 \%)$ of the papers that provided adequate spatial information. In these papers, a limited number of meteorological stations was used to represent climatic conditions of a large disease catchment area. Many of these papers used rainfall data, which varies on much shorter spatial scales, as well as temperature data from meteorological stations.

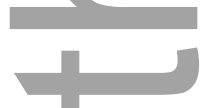

Satellite data. No spatial mismatch was identified in the studies using satellite data. Although there was no spatial mismatch, few papers addressed the issue of data autocorrelation or provided an explanation of how gridded data with different resolutions were aggregated.

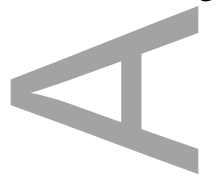

This article is protected by copyright. All rights reserved. 
Large gridded datasets. Spatial mismatch occurred in almost half (44\%) of the papers using large gridded datasets. The papers with this spatial mismatch used interpolated datasets based on very sparse meteorological station records. Despite the paucity of observations in these datasets, seven papers used them for fine spatial scale analyses. Four papers (25\%) did not provide enough information about the climate data for evaluation of spatial mismatch. In these papers, datasets that are not publically available were referenced, preventing determination of spatial mismatch. As a sensitivity analysis, the threshold was increased to 1 grid cell per $200 \mathrm{~km}^{2}$. All results remained the same, except for one paper that was no longer classified as a spatial mismatch.

\section{Discussion}

This review included 66 papers looking at meteorology and infectious diseases across Central Africa. Eleven of these papers compared disease outcomes across different seasons, and four papers did not source their meteorological data. Of the papers that did use meteorological datasets, nearly one-fourth (23\%) used data mismatched with the disease spatial scale of interest. One-fourth of the studies (25\%) did not provide enough information about their meteorological datasets to assess spatial mismatch. Spatial mismatch was most commonly identified in analyses using gridded datasets and/or local meteorological station data.

\section{Development of improved gauge-based datasets}

The primary reason for spatial mismatch is the use of datasets based on sparse and intermittent ground-based observations. Gauge-only interpolated datasets in Central Africa do not contain adequate information for local-scale analyses, yet researchers are continuing to use them. Conclusions from these studies must be interpreted cautiously due to the poor quality of the underlying meteorological data. Spatial mismatch occurs when estimates of temperature, rainfall, or humidity are obtained from locations farther than the defined decorrelation length from the area of disease data collection. If the meteorological estimates used in the analyses do not truly represent the meteorological conditions at this area of interest, the results will not be reliable or accurate. This could produce spurious relationships or hide true relationships between meteorological variables and diseases.

The recognition of sparse ground-based observational data in Africa may lead to improved coverage in the future (e.g., initiatives of the World Meteorological Organization (WMO) and TransAfrican HydroMeteorological Observatory (TAHMO). Many countries in Africa have station networks that are not publicly available ${ }^{34}$ but gaining access to these station networks would greatly improve the breadth and precision of ground-based observations. The International Research Institute for Climate and Society (IRI) has gained access to national station networks in several East African countries and, using these data streams, has created gridded data products with much greater

This article is protected by copyright. All rights reserved. 
resolution at local scales. Similar initiatives in Central Africa could improve the coverage of gaugebased datasets.

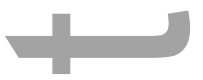

Is using satellite data a good alternative?

In the absence of adequate ground-based observations, satellite data could be a good alternative data source. Remotely sensed data have the benefit of continuity in time and space, and have spatial resolutions appropriate for local analyses. However, the accuracy of satellite-derived estimates of precipitation and temperature remains unclear. Indeed, the accuracy of satellite rainfall estimates is noted to vary by location, topography, and rainfall type. ${ }^{35}$ Despite this, some scientists have concluded that satellite-based precipitation retrieval algorithms have acceptable accuracy across Africa. ${ }^{21-24}$ For temperature, some researchers conclude that the relationship between satellite and ground-measured air temperature has not been adequately quantified in Africa, ${ }^{36}$ whereas others maintain that satellitebased estimates of temperature in Africa are an accurate representation of ground-based measurements. ${ }^{37}$ For now, researchers might rely on the recommendations by Hay and Lennon, who suggest that interpolated temperature data more accurately depict temperatures, while satellite-based estimates better represent precipitation. ${ }^{38}$ However, researchers must continue to evaluate the reliability and accuracy of satellite data for estimating ground meteorological conditions in Central Africa.

\section{Lack of information about climate data}

Many papers in this review did not provide adequate information about the meteorological data used in the analysis (27\%). Notably, four of these papers did not even provide a source for their data. Without information on the underlying data source and quality, it is impossible to assess the quality of the findings. In order to move forward in understanding the links between weather and infectious diseases, it will be important for researchers to describe and address their meteorological data sources and quality.

\section{Temporal mismatch}

The meta-analysis presented in this paper focuses on spatial mismatch of data, but there may also be temporal mismatch, which occurs when the meteorological and disease data are recorded during different time periods. The time scales over which data were collected and analyzed differ greatly in the papers included in this review. Many analyses looked at variability during 1-2 years, while others have data that spans over 20 years. Temporal mismatch was observed: for example, one paper used satellite-derived meteorological data from 2002 and disease incidence rates from 2006; another paper used meteorological data spanning 1950-1960 and daily disease data from one month in 1991. Such temporal mismatch between meteorological and disease data can also cause bias and inaccuracy of

This article is protected by copyright. All rights reserved. 
results. Further research should investigate the true prevalence and impact of temporal mismatch in papers studying meteorology and infectious diseases.

\section{Conclusion}
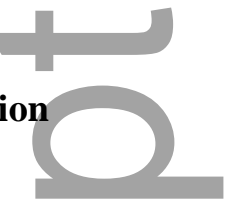

Results linking weather and infectious diseases must be supported by high-quality, spatially matched underlying data. In Central Africa, meteorological data are limited by sparse ground-based data and satellite data that have not been sufficiently validated. The scientific community must remain apprised of the limitations of the datasets available in this region and work to improve the collection, abundance, and availability of both meteorological and infectious disease data for credible analyses of interactions at the intersection of climate and infectious disease.

\section{Acknowledgements}

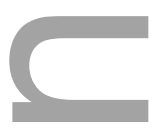

\section{Conflicts of interest}

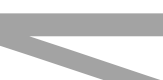

Jeffrey Shaman discloses partial ownership of SK Analytics.

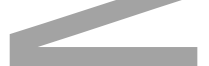

\section{Supporting Information}

Additional supporting information may be found in the online version of this article.

Table S1. Papers categorized by country.

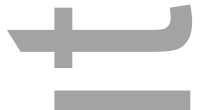

Figure S1. The number of papers published over time on climate and infectious diseases in Central Africa.

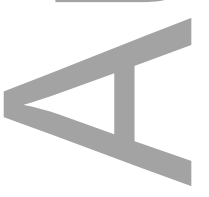

This article is protected by copyright. All rights reserved. 


\section{References}

1. WHO. 2009. Global health risks: mortality and burden of disease attributable to selected major risks. Geneva, Switzerland.

2. WHO. 2015. Health in 2015 from MDGs, millennium development goals to SDGs, sustainable development goals. Geneva, Switzerland.

3. TBFACTS.org. TB Statistics - global, regional, high burden \& MDR. Accessed January 5, 2016. http://www.tbfacts.org/tb-statistics/

4. WHO. 2012. Number of malaria deaths. Global Health Observatory (GHO) data. Accessed January 5, 2016. http://www.who.int/gho/malaria/epidemic/deaths/en/

5. WHO. 2013. HIV/AIDS. Global Health Observatory (GHO) data. Accessed January 5, 2016. http://www.who.int/gho/hiv/en/

6. Daszak, P., A.A. Cunningham, \& A.D. Hyatt. 2000. Emerging infectious diseases of wildlife threats to biodiversity and human health. Science 287: 443-449.

7. Anthony, N.M., C. Atteke, M.W. Bruford, et al. 2015. Evolution and conservation of Central African biodiversity : priorities for future research and education in the Congo Basin and Gulf of Guinea. Biotropica 471: 6-17.

8. Jones, B.A., D. Grace, R. Kock, et al. 2013. Zoonosis emergence linked to agricultural intensification and environmental change. Proceedings of the National Academy of Sciences 110: $8399-8404$.

9. Jones, K.E., N.G. Patel, M.A. Levy, et al. 2008. Global trends in emerging infectious diseases. Nature 451: 990-993.

10. Plowright, R.K., S.H. Sokolow, M.E. Gorman, et al. 2008. Causal inference in disease ecology: investigating ecological drivers of disease emergence. Frontiers in Ecology and the Environment 68: 420-429.

11. Confalonieri, U., B. Menne, R. Akhtar, et al. 2007. "Human health." In Contribution of Working Group II to the Fourth Assessment Report of the Intergovernmental Panel on Climate Change (Cambridge ). Cambridge, UK, 391-431.

12. McLeman, R., \& L. Hunter. 2010. Migration in the context of vulnerability and adaptation to

This is the author manuscript accepted for publication and has undergone full peer review but has not been through the copyediting, typesetting, pagination and proofreading process, which may lead to differences between this version and the Version of Record. Please cite this article as doi:

10.1111/nyas.13090.

This article is protected by copyright. All rights reserved. 
climate change: insights from analogues. Wiley Interdisciplinary Reviews: Climate Change 13: $450-461$.

13. Costello, A., M. Abbas, A. Allen, et al. 2009. Managing the health effects of climate change. The Lancet 373: 1693-733.

14. Byass, P. 2009. Climate change and population health in Africa: where are the scientists? Global Health Action 21: 1-4.

15. Confalonieri, U., B. Menne, R. Akhtar, et al. 2007. Human health. Climate Change 2007: Impacts, Adaptation and Vulnerability. Contribution of Working Group II to the Fourth Assessment Report of the Intergovernmental Panel on Climate Change, M.L. Parry, O.F. Canziani, J.P. Palutikof, P.J. van der Linden and C.E. Hanson, Eds., Cambridge University Press, Cambridge, UK, 391-431.

16. Chen, M.,P. Xie, CPC Quality Control Working Group, and Climate Prediction Center(CPC)/NCEP/NOAA. 2008. Quality control of daily precipitation reports at NOAA/CPC. 12th Conference on IOAS-AOLS: 1-5.

17. Love, T.B., V. Kumar, P. Xie, \& W. Thiaw. 2004. P5.4 A 20-year daily Africa precipitation climatology using satellite and gauge data. 14th Conference on Applied Climatology.

18. NOAA CPC. 2003. The NOAA Climate Prediction Center African Rainfall Estimation Algorithm Version 2.0 .

19. Becker, A., P. Finger, A. Meyer-Christoffer, et al. 2013. A description of the global landsurface precipitation data products of the Global Precipitation Climatology Centre with sample applications including centennial (trend) analysis from 1901-present. Earth System Science Data 51: 71-99.

20. Hijmans, R.J., S.E. Cameron, J.L. Parra, et al. 2005. Very high resolution interpolated climate surfaces for global land areas. International Journal of Climatology 25: 1965-1978.

21. Dinku, T., S. Chidzambwa, P. Ceccato, et al. 2008. Validation of high-resolution satellite rainfall products over complex terrain. International Journal of Remote Sensing 29: 40974110 .

22. Dinku, T., P. Ceccato, E. Grover-Kopec, et al. 2007. Validation of satellite rainfall products over East Africa's complex topography. International Journal of Remote Sensing 28: 15031526

23. Layberry, R., D.R. Kniveton, M.C. Todd, et al. 2006. Daily precipitation over southern Africa: a new resource for climate studies. Journal of Hydrometeorology 7: 149-159.

24. Maidment, R.R., D. Grimes, R.P. Allan, et al. 2014. The 30 year TAMSAT African rainfall climatology and time series (TARCAT) data set. Journal of Geophysical Research: Atmospheres 119: 10619-10644.

This article is protected by copyright. All rights reserved. 
25. Kidd, C., \& V. Levizzani. 2011. Status of satellite precipitation retrievals. Hydrology and Earth System Sciences 15: 1109-1116.

26. Tomlinson, C.J., L. Chapman, J.E. Thornes, \& C. Baker. 2011. Remote sensing land surface temperature for meteorology and climatology: a review. Meteorological Applications 18: 296306

27. Harris, I., P.D. Jones, T.J. Osborn, \& D.H. Lister. 2014. Updated high-resolution grids of monthly climatic observations - the CRU TS3.10 dataset. International Journal of Climatology 34: $623-642$.

28. Diem, J.E., S.J. Ryan, J. Hartter, \& M.W. Palace. 2014. Satellite-based rainfall data reveal a recent drying trend in central equatorial Africa. Climatic Change 126: 263-272.

29. Diem, J.E., J. Hartter, S.J. Ryan, and M.W. Palace. 2014. Validation of satellite rainfall products for Western Uganda. Journal of Hydrometeorology 15: 2030-2039.

30. WHO. 2013. Population estimates from the WHO. Accessed January 5, 2016. http://www.who.int/countries

31. Moron, V, A.W. Robinson, M.N. Ward, et al. 2007. Spatial coherence of tropical rainfall at the regional scale. Journal of Climate 20: 5244-5263

32. Ricciardulli, L., \& P.D. Sardeshmukh. 2002. Local time and space scales of organized tropical deep convection. Journal of Climate 15: 2775-90.

33. Smith, D.F., A. J. Gasiewski, D.L. Jackson, \& G.A. Wick. 2005. Spatial scales of tropical precipitation inferred from TRMM microwave imager data. IEEE Transactions on Geoscience and Remote Sensing 43: 1542-51

34. Brew, D., R. Washington, M. Harrison, et al. 2004. A report commissioned by the UK government to review African climate science, policy and options for action.

35. Han, W.S., S. Burian, \& M. Shepherd. 2011. Assessment of satellite-based rainfall estimates in urban areas in different geographic and climatic regions. Natural Hazards 56: 733-747.

36. Vancutsem, C., P. Ceccato, T. Dinku, \& S.J. Connor. 2010. Evaluation of MODIS land surface temperature data to estimate air temperature in different ecosystems over Africa. Remote Sensing of Environment 114: 449-465.

37. Ceccato, P., C. Vancutsem, \& M. Temimi. 2010. Monitoring air and land surface temperatures from remotely sensed data for climate-human health applications. Geoscience and Remote Sensing Symposium (IGARSS). 178-180.

38. Hay, S.I., \& J.J. Lennon. 1999. Deriving meteorological variables across Africa for the study and control of vector-borne disease: a comparison of remote sensing and spatial interpolation of climate. Tropical Medicine \& International Health 4: 58-71.

This article is protected by copyright. All rights reserved. 
Figure legends:

Figure 1. Spatial distribution of gauge $(\mathrm{GHCN})$ meteorological stations in Africa. Central African countries are indicated in grey.

Table 1. Climate data sources, including satellite sensors and gridded data sets

\begin{tabular}{|c|c|c|c|c|}
\hline Sensor/data set & Satellite/source & $\begin{array}{l}\text { Spatial } \\
\text { resolution }\end{array}$ & $\begin{array}{l}\text { Temporal } \\
\text { resolution }\end{array}$ & Dates \\
\hline \multicolumn{5}{|c|}{ High-resolution sensors } \\
\hline TM & Landsat 5 (USGS, NASA) & $\begin{array}{l}120 \mathrm{~m} \text { (TIRS)-LST } \\
30 \mathrm{~m} \text { (VNIR)-NDVI }\end{array}$ & 16 days & 1984-201 \\
\hline ETM+ & Landsat 7 (USGS, NASA) & $\begin{array}{l}60 \mathrm{~m} \text { (TIRS)-LST } \\
30 \mathrm{~m} \text { (VNIR)-NDVI }\end{array}$ & 16 days & 1999-pre \\
\hline OLI & Landsat 8 (USGS, NASA) & $\begin{array}{l}100 \mathrm{~m} \text { (TIRS)-LST } \\
30 \mathrm{~m} \text { (VNIR)-NDVI }\end{array}$ & 16 days & 2013-pre \\
\hline ASTER & Terra (NASA, METI) & $\begin{array}{l}90 \mathrm{~m} \text { (TIRS)-LST } \\
15 \mathrm{~m} \text { (VNIR)-NDVI }\end{array}$ & 16 days & 1999- \\
\hline \multicolumn{5}{|c|}{ Moderate-resolution sensors } \\
\hline AVHRR & NOAA (multiple) & $1.1 \mathrm{~km}$ & $12 \mathrm{~h}$ & 1979-pres \\
\hline MODIS & Terra, Aqua (NASA) & $\begin{array}{l}1 \mathrm{~km}-\mathrm{LST} \\
250 \mathrm{~m}-1 \mathrm{~km}-\mathrm{NDVI}\end{array}$ & $12 \mathrm{~h}$ & 2000-pre \\
\hline
\end{tabular}

This article is protected by copyright. All rights reserved. 


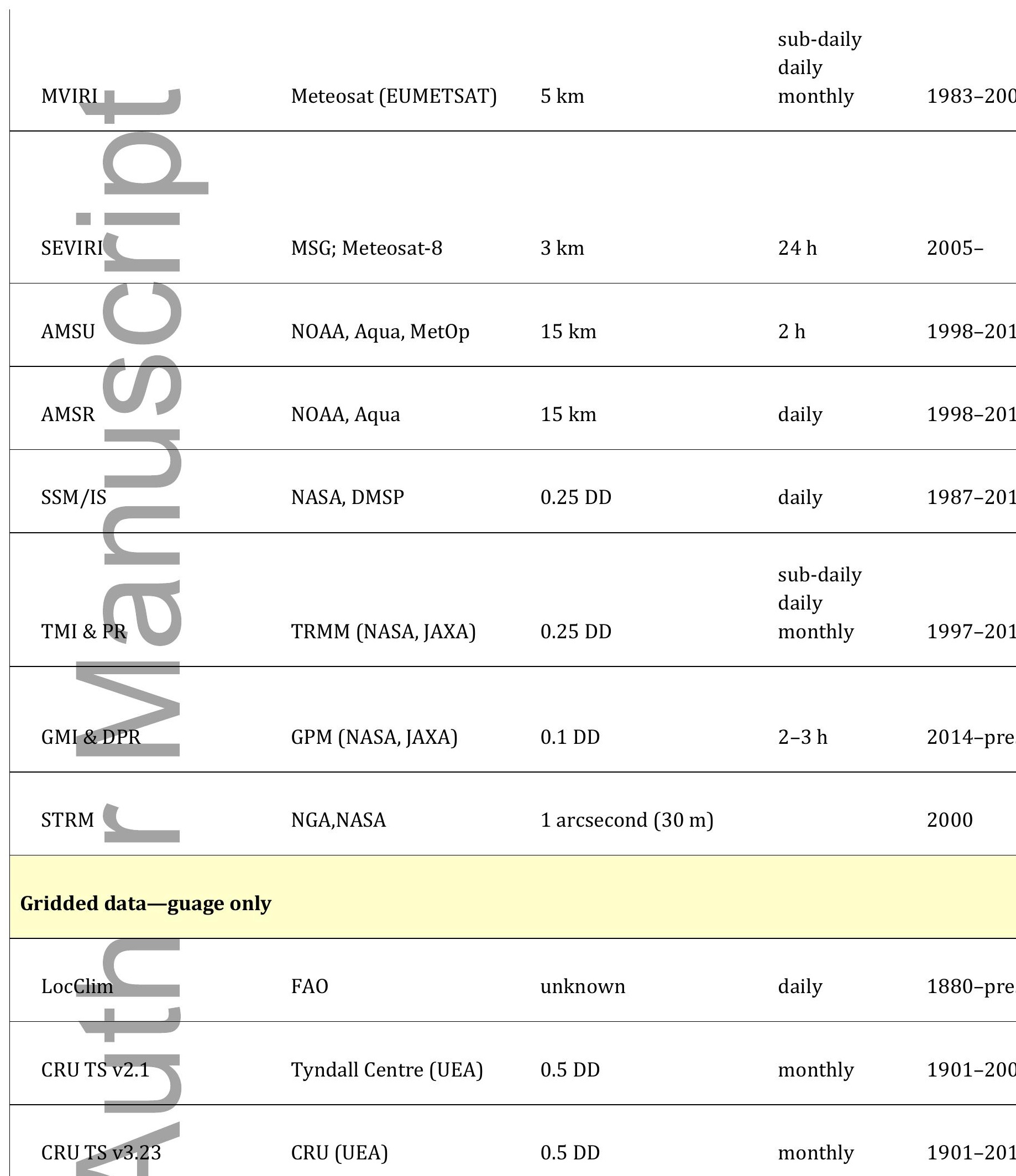

This article is protected by copyright. All rights reserved. 


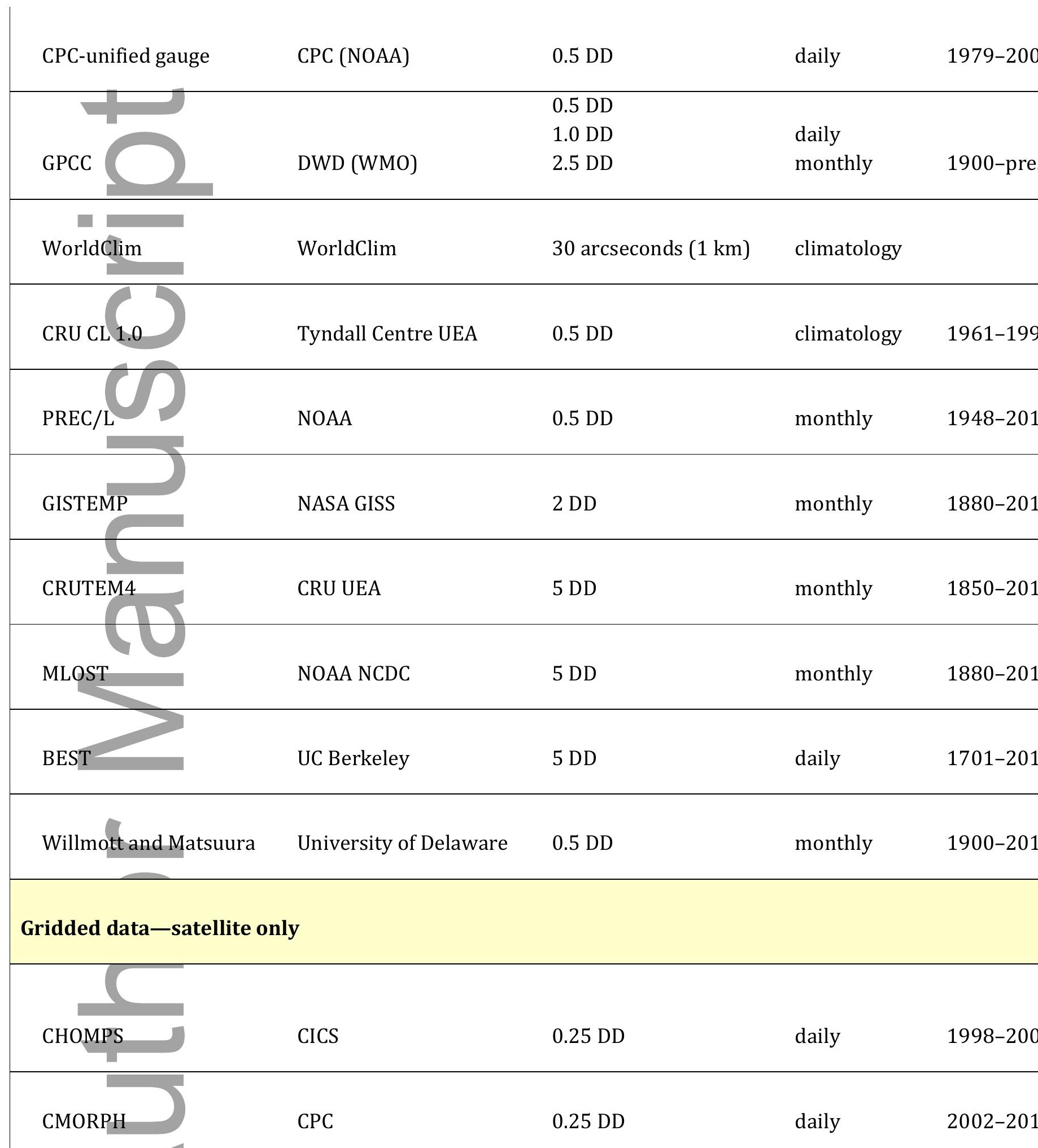

This article is protected by copyright. All rights reserved. 


\begin{tabular}{|c|c|c|c|c|}
\hline eMODIS & $\begin{array}{l}\text { MODIS } \\
\text { FEWS (USGS/EROS) }\end{array}$ & $250 \mathrm{~m}$ & 10 days & 2000-pre \\
\hline GIMMS & AVHRR (NOAA) & $8 \mathrm{~km}$ & bi-monthly & $1981-20$ \\
\hline GlobCover & MERIS; ENVISAT (ESA) & $300 \mathrm{~m}$ & & $\begin{array}{l}2004-20 \\
2006-20\end{array}$ \\
\hline GLC2000 & SPOT 4 & $20 \mathrm{~m}$ & & 2000 \\
\hline IGAD/NILE MMbd & AVHRR & $1.1 \mathrm{~km}$ & $12 \mathrm{~h}$ & 1979-pr \\
\hline
\end{tabular}

\section{Gridded data-satellite gauge}

\begin{tabular}{|c|c|c|c|c|}
\hline RFE 2.0 & $\mathrm{CPC}$ & $0.1 \mathrm{DD}$ & daily & 2001-pre \\
\hline ARC 2.0 & СРC & $0.1 \mathrm{DD}$ & $\begin{array}{l}\text { daily } \\
\text { monthly }\end{array}$ & 1983-pre \\
\hline CMAP & NOAA CPC & $2.5 \mathrm{DD}$ & monthly & 1979-201 \\
\hline GPCP & GSFC (NASA) & $1 \mathrm{DD}$ & daily & 1996-201 \\
\hline GPCP & GSFC (NASA) & $2.5 \mathrm{DD}$ & monthly & 1979-201 \\
\hline PERSIANN-CDR & CHRS & $0.25 \mathrm{DD}$ & daily & 1983-201 \\
\hline TMPA & NASA \& JAXA & $0.25 \mathrm{DD}$ & $\begin{array}{l}\text { sub-daily } \\
\text { dail } \\
\text { monthly }\end{array}$ & 1998-201 \\
\hline
\end{tabular}

This article is protected by copyright. All rights reserved. 
$\begin{array}{lll}\text { IMERG NASA } & \text { N DD }\end{array}$

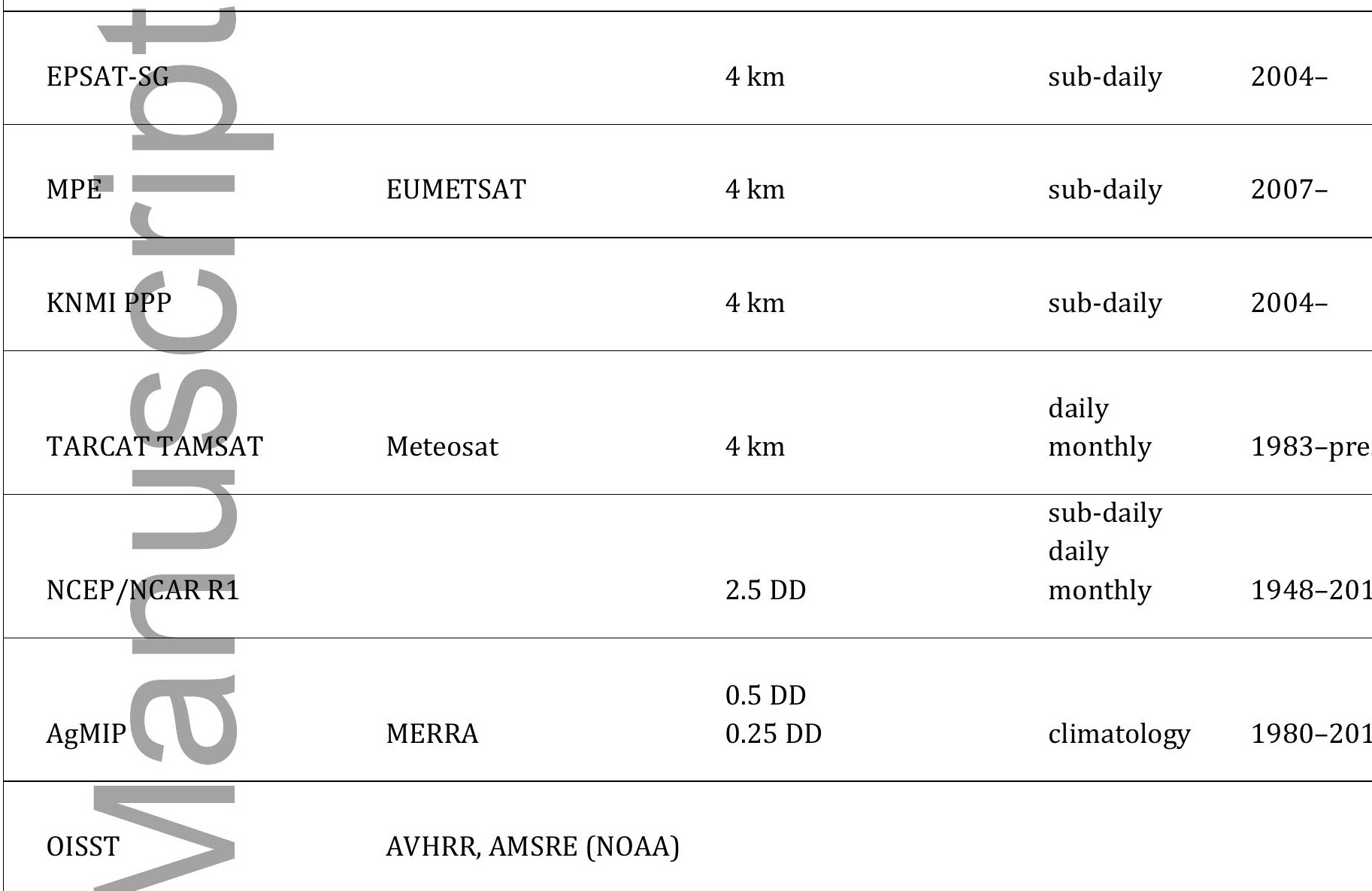

\section{Other}

The Spatial

Characterization

Tool

monthly

This article is protected by copyright. All rights reserved. 
Data Bank

NOTE: $1 \mathrm{DD}=111.32 \mathrm{~km}$ at equator; 30 arcseconds $=0.86 \mathrm{~km}^{2}\left(1 \mathrm{~km}^{2}\right)$.

Table 2. Summary of data from 104 global historical climate network (GHCN) stations for Central African countries

\begin{tabular}{|c|c|c|c|c|c|c|c|c|}
\hline country & $\begin{array}{r}\text { Stati } \\
\text { on }\end{array}$ & $\begin{array}{c}\text { Start } \\
\text { date }\end{array}$ & $\begin{array}{l}\text { End } \\
\text { date }\end{array}$ & $\begin{array}{c}\text { Day } \\
s\end{array}$ & $\begin{array}{c}\text { Area } \\
\left(\mathrm{km}^{2}\right)\end{array}$ & $\begin{array}{r}\text { Density } \\
\text { (per } \\
100,000 \mathrm{k} \\
\mathrm{m}^{2} \text { ) }\end{array}$ & $\begin{array}{r}\text { Recordi } \\
\text { ngs } \\
\text { with } \\
\text { data }\end{array}$ & $\begin{array}{r}\text { Covera } \\
\text { ge }\end{array}$ \\
\hline
\end{tabular}

\begin{tabular}{|c|c|c|c|c|c|c|c|c|}
\hline Angola & 7 & $\begin{array}{r}1 / 28 / 5 \\
3\end{array}$ & $\begin{array}{r}10 / 20 / \\
15\end{array}$ & $\begin{array}{r}221 \\
79\end{array}$ & $\begin{array}{r}1,246,7 \\
00\end{array}$ & 0.56 & 15703 & $\begin{array}{r}10.11 \\
\%\end{array}$ \\
\hline Burundi & 2 & $1 / 1 / 50$ & $\begin{array}{r}12 / 31 / \\
89\end{array}$ & $\begin{array}{r}146 \\
09\end{array}$ & 27,834 & 7.19 & 27941 & $\begin{array}{r}95.63 \\
\%\end{array}$ \\
\hline $\begin{array}{l}\text { Central Afri } \\
\text { Republic }\end{array}$ & 17 & $1 / 1 / 50$ & $\begin{array}{r}10 / 20 / \\
15\end{array}$ & $\begin{array}{r}240 \\
33\end{array}$ & $\begin{array}{r}622,98 \\
4\end{array}$ & 2.73 & 160597 & $\begin{array}{r}39.31 \\
\%\end{array}$ \\
\hline Cameroon & 5 & $1 / 1 / 48$ & $\begin{array}{r}10 / 20 / \\
15\end{array}$ & $\begin{array}{r}247 \\
64\end{array}$ & $\begin{array}{r}475,44 \\
2\end{array}$ & 1.05 & 16702 & $\begin{array}{r}13.49 \\
\%\end{array}$ \\
\hline Chad & 11 & $1 / 1 / 50$ & $\begin{array}{r}10 / 20 / \\
15\end{array}$ & $\begin{array}{r}240 \\
33\end{array}$ & $\begin{array}{r}1,284,0 \\
00\end{array}$ & 0.86 & 109779 & $\begin{array}{r}41.53 \\
\%\end{array}$ \\
\hline $\begin{array}{l}\text { Democratic Rep } \\
\text { of Congo }\end{array}$ & 13 & $\begin{array}{r}2 / 18 / 7 \\
3\end{array}$ & $\begin{array}{r}10 / 20 / \\
15\end{array}$ & $\begin{array}{r}155 \\
84\end{array}$ & $\begin{array}{r}2,344,8 \\
58\end{array}$ & 0.55 & 4278 & $2.11 \%$ \\
\hline Equatorial Guinea & 2 & $5 / 1 / 96$ & $\begin{array}{r}10 / 20 / \\
15\end{array}$ & $\begin{array}{r}711 \\
1\end{array}$ & 28,051 & 7.13 & 568 & $3.99 \%$ \\
\hline Gabon & 19 & $1 / 1 / 50$ & $\begin{array}{r}10 / 20 / \\
15\end{array}$ & $\begin{array}{r}240 \\
33\end{array}$ & $\begin{array}{r}267,66 \\
8\end{array}$ & 7.10 & 155103 & $\begin{array}{r}33.97 \\
\%\end{array}$ \\
\hline Republic of Congo & 15 & $3 / 1 / 47$ & $\begin{array}{r}10 / 20 / \\
15\end{array}$ & $\begin{array}{r}250 \\
70\end{array}$ & $\begin{array}{r}342,00 \\
0\end{array}$ & 4.39 & 151355 & $\begin{array}{r}40.25 \\
\%\end{array}$ \\
\hline Rwanda & 1 & $\begin{array}{r}6 / 29 / 7 \\
3\end{array}$ & $\begin{array}{r}10 / 20 / \\
15\end{array}$ & $\begin{array}{r}154 \\
53\end{array}$ & 26,338 & 3.80 & 3513 & $\begin{array}{r}22.73 \\
\%\end{array}$ \\
\hline
\end{tabular}

This article is protected by copyright. All rights reserved. 
South Sudan

Uganda

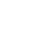

$4 \quad 1 / 1 / 50$

$81 / 1 / 26$
$10 / 20 / \quad 240 \quad 619,74$

$\begin{array}{lll}15 & 33 & 5\end{array}$

$12 / 31 / 222 \quad 241,55$

$\begin{array}{lll}86 & 79 & 0\end{array}$

$86-79$
$0.65 \quad 34871$

36.27

$\%$

69.20

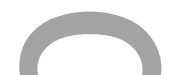

3.31

123329

NoTE: Coverage is the number of days of temperature and precipitation observations divided by the total number of days of recording possible, calculated as the number of days between the first and last recording dates (days) multiplied by the total number of stations for each country (station). Area estimates are from United Nations Statistics Division (unstats.un.org/unsd/demographic).

Table 3. The key terms used for Web of Science searches

\begin{tabular}{|c|c|c|}
\hline Infectious disease & Meteorology & Country \\
\hline Tuberculosis & Climate & Chad \\
\hline Malaria & Meteorology & Central African Republic \\
\hline Respiratory infection & Hydrology & South Sudan \\
\hline Pneumonic & Humidity & Democratic Republic of Congo \\
\hline Mosquito $^{a}$ & Water & Rwanda \\
\hline Meningitis & Precipitation & Congo \\
\hline Diarrhea $^{a}$ & Rainfall & Gabon \\
\hline Diarrhoe & Temperature & Equatorial Guinea \\
\hline Cholera & Dew point & Cameroon \\
\hline Influenza & & Uganda \\
\hline Infection $^{a}$ & & Burundi \\
\hline Zoono $^{a}$ & & Angola \\
\hline Vector-borne & & \\
\hline Water-borne & & \\
\hline
\end{tabular}

This article is protected by copyright. All rights reserved. 
Virus

Bacteria

Helminth

Protozoa

Fever

Worm

Parasite $^{a}$

NOTE: The key terms used for Web of Science searches were separated into three categories: infectious disease, meteorology, and country. Every search contained one key term from each category.

${ }^{a}$ The search was conducted with all completions of the indicated word.

Table 4. Papers categorized by disease topic

\begin{tabular}{llc} 
Mode of transmission & Disease & $\begin{array}{c}\text { Number of } \\
\text { papers (\%) }\end{array}$ \\
\hline Vector-borne & Malaria & $40(60.6 \%)$ \\
\hline & African trypanosomiasis & $29(43.9 \%)$ \\
& Plague & $4(6.0 \%)$ \\
& Dengue fever & $1(1.5 \%)$ \\
& Avian malaria & $1(1.5 \%)$ \\
& Onchocherciasis & $1(1.5 \%)$ \\
\hline Yater-borne & Yellow fever & $1(1.5 \%)$ \\
\hline
\end{tabular}

This article is protected by copyright. All rights reserved. 


\begin{tabular}{|c|c|c|}
\hline & Schistosomiasis & $6(9.0 \%)$ \\
\hline & Cholera & $6(9.0 \%)$ \\
\hline & Guinea worm & $1(1.5 \%)$ \\
\hline & Coliform bacteria & $1(1.5 \%)$ \\
\hline a & Hepatitis E & $1(1.5 \%)$ \\
\hline \multirow[t]{5}{*}{ Respiratory } & & $7(10.6 \%)$ \\
\hline & Meningitis & $1(1.5 \%)$ \\
\hline & Tuberculosis & $1(1.5 \%)$ \\
\hline & Acute respiratory infections & $1(1.5 \%)$ \\
\hline & Influenza & $1(1.5 \%)$ \\
\hline \multirow[t]{5}{*}{ Direct contact } & & $6(9.0 \%)$ \\
\hline & Monkeypox & $3(4.5 \%)$ \\
\hline & Ebola & $1(1.5 \%)$ \\
\hline & Mycetoma & $1(1.5 \%)$ \\
\hline & Hookworm & $1(1.5 \%)$ \\
\hline \multirow[t]{3}{*}{ Fecal oral } & & $2(3.0 \%)$ \\
\hline & Ascariasis & $1(1.5 \%)$ \\
\hline & Trichuriasis & $1(1.5 \%)$ \\
\hline
\end{tabular}

NотE: Several papers studied multiple diseases and were placed in all relevant disease categories.

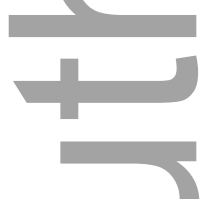

Table 5. Summary of meteorological data used in included papers

This article is protected by copyright. All rights reserved. 
Meteorological data sources

\begin{tabular}{lc}
\hline Local meteorological stations & $22(33.3 \%)$ \\
Large gridded datasets & $16(24.2 \%)$ \\
Seasons & $12(18.2 \%)$ \\
Satellite data & $10(15.2 \%)$ \\
Directly measured & $8(12.1 \%)$ \\
Unknown & $4(6.0 \%)$ \\
\end{tabular}

NOTE: Several papers used multiple types of data and are included in all relevant data categories.

Table 6. Summary of disease data types used in papers

\begin{tabular}{lr} 
Disease data type & Papers (\%) \\
\hline Human disease records & $36(54.4 \%)$ \\
Animal host or vector sampling/collection/trapping & $19(28.7 \%)$ \\
Primary human data collection & $15(22.7 \%)$ \\
Water samples & $5(7.5 \%)$ \\
Species occurrence data & $2(3.0 \%)$ \\
\end{tabular}

NOTE: Several papers used multiple types of data and are included in all relevant data categories.

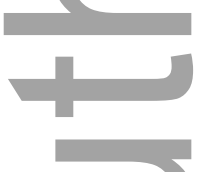

Table 7. Occurrence of spatial mismatch stratified by the type of climate data used

Data type Unknown Mismatched $\begin{gathered}\text { Not } \\ \text { mismatched Total }\end{gathered}$

This article is protected by copyright. All rights reserved. 


\begin{tabular}{lcccc}
\hline Directly measured & 0 & 0 & 8 & 8 \\
Local meteorological station & 10 & 6 & 6 & 22 \\
Satellite & 0 & 0 & 10 & 10 \\
Large gridded dataset & 4 & 7 & 5 & 16 \\
Total & 14 & 13 & 29 & 56 \\
& & & & \\
\hline
\end{tabular}

NOTE: "Unknown" indicates that insufficient information was provided to determine spatial mismatch. Each cell contains the total number of papers in that category.

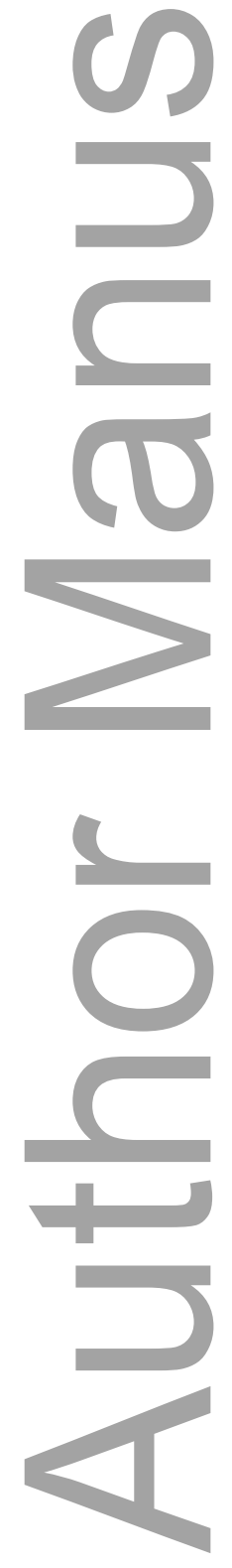

This article is protected by copyright. All rights reserved. 